\title{
Defining geo-habitats for groundwater ecosystem assessments: An example from England and Wales (UK)
}

\author{
Damiano C. Weitowitz ${ }^{1 *}$, Louise Maurice ${ }^{2}$, Melinda Lewis ${ }^{2}$, John P. Bloomfield ${ }^{2}$, Julia Reiss ${ }^{1}$, \\ Anne L. Robertson ${ }^{1}$ \\ ${ }^{1}$ University of Roehampton, Department of Life Sciences, Whitelands College, Holybourne \\ Avenue, SW15 4JD, London, United Kingdom. email: weitowid@roehampton.ac.uk \\ ${ }^{2}$ British Geological Survey, Maclean Building, Crowmarsh Gifford, Wallingford, OX10 8BB, \\ Oxfordshire, United Kingdom \\ *Corresponding author
}

Keywords: habitat, typology, heterogeneity, quality, hydrochemistry

\begin{abstract}
Groundwater ecosystems comprising micro-organisms and metazoans provide an important contribution to global biodiversity. Their complexity depends on geology, which determines the physical habitat available, and the chemical conditions within it. Despite this, methods of classifying groundwater habitats using geological data are not well established, and researchers have called for higher resolution habitat frameworks. A novel habitat typology for England and Wales (UK) is proposed, which distinguishes 11 geological habitats (geohabitats) on hydrogeological principles and maps their distribution. Hydrogeological and hydrochemical data are used to determine the characteristics of each geo-habitat, and demonstrate their differences. Using these abiotic parameters, a new method to determine abiotic habitat quality is then developed. The geo-habitats had significantly different characteristics validating the classification system. Karstic and porous habitats were generally of higher quality than fractured habitats. All geo-habitats were highly heterogeneous, containing both high quality habitat patches that are likely to be suitable for fauna, and areas of low quality that may limit faunal distributions. Overall, $70 \%$ of England and Wales are covered by lower quality fractured habitats, with only $13 \%$ covered by higher quality habitats. The main areas of high quality habitats occur in central England as northsouth trending belts, possibly facilitating dispersal along this axis. They are separated by low quality geo-habitats that may prevent east-west dispersal of fauna. In south-west England and in Wales suitable geo-habitats occur as small isolated patches. Overall, this paper provides a new national-scale typology that is adaptable for studies in other geographic areas.
\end{abstract}




\section{Introduction}

The earth's rocks and groundwater form unique, important habitats. Obligate groundwater invertebrates (called stygobites), and sometimes vertebrates, are the top-level consumers in these truncated communities. They feed on a variety of organisms, including protozoans, microbes and fungi (Gibert et al., 1994; Boulton et al., 2008; Weitowitz, 2017). These groundwater communities are likely to be important for their role in biogeochemical cycling and pollutant attenuation (Mattison et al., 2002, 2005). Stygobites also make a unique contribution to biodiversity because they are not found in other habitats, and have high rates of endemism and ancient ancestral lineages (Finston \& Johnson, 2004; Lefebure et al., 2007; Mclnerney et al., 2014). Understanding the processes shaping groundwater ecosystems is important because they may be impacted by anthropogenic stressors, such as water abstraction, changes in water flow patterns, and the leaching of agrochemicals (Klove et al., 2011; Foster et al., 2016).

Groundwater ecosystems primarily depend on geology, which provides the physical habitat and determines hydrochemistry (Datry et al., 2005; Hahn, 2006; Maurice \& Bloomfield, 2012). Three types of physical structures are available as groundwater habitats: Pore spaces, fractures, and karstic voids / caves. The habitat quality (i.e. their ability to support more complex groundwater ecosystems) depends on the size and density of openings in the rock, as these, together with the lithology, determine the amount of space and the ambient water chemistry present in the subsurface (Goldscheider et al., 2006). Habitat quality in unconsolidated sediments depends on pore space size, and is generally better in coarse-grained aquifers (Dole-Olivier et al., 2009; Hahn, 2009; Hahn \& Fuchs, 2009; Malard et al., 2009). In fractured rocks, habitat quality is highly variable and depends on fracture size, density and connectivity (Hahn \& Matzke, 2005; Hahn \& Fuchs, 2009; Maurice \& Bloomfield, 2012). Karstic rocks generally have high habitat quality, because dissolution has transformed fractures into large voids and cave systems with rapid water flow and surface connectivity (Danielopol et al., 2004; Malard et al., 2009; Robertson et al., 2009).

Grouping of habitats is frequently done for surface ecosystems and plays an essential role in ecology and conservation (Russ \& Montgomery, 2002; Canadas et al., 2005; Russo et al., 2005). In groundwater ecosystem studies, geologies have generally been amalgamated into broad habitat categories (e.g. Castellarini et al., 2007; Dole-Olivier et al., 2009; Hahn \& Fuchs, 2009; Robertson et al., 2009; Johns et al., 2015). While fractured rocks are generally characterised by communities of low diversity and abundance (Hahn \& Fuchs, 2009), karstic and porous rocks have been found to harbour more complex communities with higher diversity and abundance of both invertebrates and microbial biocenoses (Goldscheider et al., 2006; Robertson et al., 2009; Stoch et al., 2009; Gibert et al., 2009). At the continental scale, a groundwater habitat map based on the European hydrogeological map has been developed (Cornu et al., 2013).

The quality of groundwater habitats also depends on water chemistry. Dissolved oxygen (DO), dissolved organic carbon (DOC), calcium (Ca) and nitrate $\left(\mathrm{NO}_{3}\right)$ influence groundwater ecosystems, and the distribution of stygobites (Datry et al., 2005; Goldscheider et al., 2006; Hahn, 2006; Dole-Olivier et al., 2009; Hahn \& Fuchs, 2009; Griebler et al., 2010). Generally, rocks with higher permeability are thought to provide higher levels of oxygen (due to faster groundwater movement) and organic detritus than less permeable rocks (Hahn, 2006; Bork et al., 2009; Maurice \& Bloomfield, 2012). 
The need for more detailed typologies of groundwater habitats, incorporating hydrogeological and hydrochemical data, has been highlighted (Castellarini et al., 2007; Tomlinson \& Boulton, 2010; Larned, 2012; Stein et al., 2012). Grouping geological strata into only a few units reduces the explanatory power of habitat frameworks, a problem which is further exacerbated by the heterogeneity of rocks (Stoch et al., 2009; Larned, 2012). A more detailed approach is necessary to assess species-habitat associations (Datry et al., 2005; Hancock et al., 2005), providing scientists with an improved tool for management and conservation decisions (Hahn, 2009).

This paper aims to

- use lithological and hydrogeological information to develop a geo-habitat typology for England and Wales.

- establish and compare the abiotic conditions (transmissivity, $\mathrm{DO}, \mathrm{DOC}, \mathrm{NO}_{3}$ and $\mathrm{Ca}$ ) in the geo-habitats, and develop a habitat quality scoring system.

- assess the distribution and connectivity of geo-habitats in England and Wales to provide a framework for future ecological studies.

\section{Methodology}

\subsection{Assessing geo-habitat distribution}

\section{Determining geo-habitat categories}

Initially bedrock was separated into karstic, porous and fractured rock as in previous studies (e.g. Galassi et al., 2009; Hahn \& Fuchs, 2009; Malard et al., 2009; Martin et al., 2009). Further subdivisions were made (Fig. 1), based on differences in hydrogeological features (e.g. karstification, fractures, and pore space sizes), which affect the available habitat space and water chemistry.

Karstic aquifers were grouped into four habitats (Fig. 1, step b). These were based on previous classifications that suggest that karstification increases from the Cretaceous Chalk, through Permian limestone, to the Jurassic limestone and then the Carboniferous limestone (Atkinson \& Smart, 1981; Worthington \& Ford, 2009). Although caves are rare in the Chalk, solutional fissures and small conduits commonly occur (Maurice et al., 2006, 2012). The Permian limestone is dolomitic and mildly karstic in nature. In the Jurassic limestone caves are slightly more common, although the predominant habitat is solutional fissures and conduits. The Carboniferous limestone has extensive cave systems up to $100 \mathrm{~km}$ in length, providing caves and solutional fissures as habitat.

Fractured rocks were separated into four geo-habitats (Fig. 1 step c), based on the size and density of fracturing. Fractured Sandstone has a relatively well developed fracture network, supporting moderate permeability (Jones et al., 2000). Igneous Rock and Metamorphic Rock both have low fracture densities, and therefore low permeability (Jones et al., 2000). However, because the groundwater chemistry (e.g. DO and Ca) in Igneous and Metamorphic Rock in the study area differs considerably (Smedley \& Allen, 2004; Shand et al., 2005), they were retained as separate geo-habitats. Mudstones \& Siltstones are consolidated fine-grained sedimentary rocks, which have limited fracture networks (Jones et al., 2000). 
Unconsolidated sediments were divided into Small-Pore Unconsolidated and LargePore Unconsolidated sediments based on differences in grain and pore space size (Fig. 1, step d). Sediments with grain sizes below $2 \mathrm{~mm}$ (clay, silt, sand) were classified as SmallPore Unconsolidated (Wentworth, 1922), while sediments with larger grain sizes were classified as Large-Pore Unconsolidated (e.g. gravel, flints, pebbles, boulders) (Jones et al., 2000). More recent Quaternary superficial deposits also form porous habitats, but were not included in this study because there is insufficient information on their physical and chemical properties.

Rocks with a mixture of intergranular and fracture water flow were assigned to a mixed rock geo-habitat (Fig. 1, step a). This comprised Mixed Sandstone (mainly of PermoTriassic age) which has both cemented and unconsolidated sections, dominated by fracture and intergranular flow respectively (Allen et al., 1997). This geo-habitat is characterised by highly variable fracture sizes, fracture density, cementation and mudstone content (Allen et al., 1997).

\section{Assigning geological units to geo-habitats}

Geological mapping of the UK is available at the 1:625,000, 1:250,000, 1:50,000 and $1: 10,000$ scales. A scale of 1:50,000 was used as it provides geological detail and accurate geological boundaries. ArcGIS 10.1 (ESRI, 2011) was used to visualise the 10,000 different geological units in England and Wales.

Units were first sorted by age, as this determines lithological features, such as the extent of karstification in carbonate rocks or consolidation in other sedimentary rocks (Worthington \& Ford, 2009). Lithologies in the attribute tables (available from BGS; Smith et al., 2013) are sorted by dominance, and a geological unit was assigned to the geo-habitat that corresponded to the dominant lithology.

For some geological units, the categorisation was more complex. To decide whether sandstones were included in 'Mixed Sandstone' or 'Fractured Sandstone' information on age, consolidation and flow type was compiled from the BGS online lexicon (http://www.bgs.ac.uk/lexicon) and the aquifer properties manuals for England and Wales (Allen et al., 1997; Jones et al., 2000). As part of the grouping process geological units with different characteristics sometimes had to be included in the same geo-habitat (Table 1).

\subsection{Assessing Geo-Habitat Characteristics}

\section{Data Collection}

Transmissivity and porosity data were obtained from the UK aquifer properties manuals, including 1724 transmissivity values from pumping tests and 518 porosity values (both summary values) from core samples at different locations (see Table 2) (Allen et al., 1997; Jones et al., 2000). The distribution of sites with transmissivity data was uneven across geohabitats (Fig. S1), as pumping tests are often only performed on successful boreholes with relatively high yields. Porosity samples had less extensive coverage (Fig. S2). Sampling coverage was evenly distributed for Mixed Sandstone and the Chalk, while for other geohabitats such as Fractured Sandstone and Igneous Rock no data were available from south- 
west England and south-west Wales, respectively (Fig. S2). There have been few porosity measurements in Small-Pore and Large-Pore Unconsolidated sediments.

Hydrochemical data, including $\mathrm{DO}, \mathrm{DOC}, \mathrm{NO}_{3}$ and $\mathrm{Ca}$, were obtained from the British Geological Survey (BGS) and Environment Agency (EA) Baseline Chemistry Report Series of aquifers in the UK (e.g. Ander et al., 2004; Cobbing et al., 2004; Smedley et al., 2004). Because specific location data were not available for these samples, published reports were used to identify the aquifers the samples came from (British Geological Survey, 2016). These reports predominantly cover the main aquifers, and particularly for Igneous and Metamorphic rocks do not cover the full range of these rocks present in England and Wales. Hydrochemical data from a faunal distribution study in south-west England were also used (Johns et al., 2015). In total 1363 DO samples, 998 DOC samples, $2342 \mathrm{NO}_{3}$ samples and 2898 Ca samples were available (see Table 3). For several geo-habitats (e.g. the southern Chalk, Smedley et al., 2003; Moderately Karstic Limestone, Griffiths et al., 2006) some data came from confined sites (i.e. covered by overlying strata of low permeability), which typically have low oxygen and nutrient concentrations not representative of the rest of the aquifer. However, these could not be identified in the anonymised data set, which was therefore used in its entirety.

Some of the DO concentrations were very high, possibly due to poor calibration. For DO records from Johns et al. (2015), temperature data were used to determine the maximum possible DO (VLMP, 2016). All values above these thresholds were excluded from the analysis. For DO records from the baseline chemistry reports, temperatures were unavailable and the average groundwater temperature of $10.5{ }^{\circ} \mathrm{C}$ from a long-term study (Bloomfield et al., 2013) was used to identify the maximum possible DO of $11.5 \mathrm{mg} / \mathrm{L}$, allowing for a small amount of oversaturation.

\section{Comparing Geo-Habitat Characteristics}

Summary statistics of hydrogeological and hydrochemical variables were calculated in $R(R$ Development Core Team, 2017). To determine whether data were normally distributed, histograms, q-q plots and Shapiro-Wilk normality tests were conducted.

As all variables were non-normally distributed, non-parametric Kruskal-Wallis tests were used to test for significant differences between geo-habitats. When these were significant $(P<0.05)$ post-hoc multiple pairwise comparisons with Bonferroni corrections were performed in the R 'Psych' package (Revelle, 2016) to determine which geo-habitats differed. To reduce the number of comparisons, the geo-habitat with the lowest mean transmissivity was used as a point of comparison because this was likely to be the least suitable habitat.

Following Gagic et al. (2016), a principal component analysis was conducted in the $\mathrm{R}$ package 'missMDA' (Josse \& Husson, 2016) to assess abiotic characteristics in broad habitat groups (karstic, porous, fractured). This package deals with missing values in the dataset by using a regularised mean substitute method, which takes the parameter mean and correlations between variables into account (Josse \& Husson, 2012). As the PCA was conducted on mixed-type data, categorical variables were transformed into a disjunctive data table, before being scaled to unit variance using MCA scaling (Josse \& Husson, 2012). 


\subsection{Evaluation of Geo-Habitat Quality}

To assess the quality of geo-habitats, 7 parameters known to influence groundwater communities were considered. These were DO (Gibert et al., 1994; Dole-Olivier et al., 2009), DOC (Datry et al., 2005; Hahn, 2006), NO (Stein et al., 2010), Ca (Rukke, 2002), transmissivity (permeability) (Hahn, 2006; Bork et al., 2009), cave development (Culver \& Sket, 2000) and physical habitat space (Dole-Olivier et al., 2009). A method was developed to determine overall habitat suitability. Critical parameter thresholds (below which ecosystem health would be likely impaired) were identified using previous studies. These thresholds were used as cut-off points to identify the ratio of good to bad quality patches.

\section{Identification of thresholds and additional parameters}

A critical threshold of $1 \mathrm{mg} / \mathrm{L}$ was set for DO, as previous studies found this concentration to be the lower critical survival limit of groundwater invertebrates (Malard \& Hervant, 1999; Hahn, 2006). For DOC, the main food source in groundwater, a critical threshold of $0.4 \mathrm{mg} / \mathrm{L}$ was used, because this was the concentration below which taxa were lost from groundwater communities in a study by Datry et al. (2005). For $\mathrm{NO}_{3}$, an important additional resource for bacteria (Stein et al., 2010), the threshold was set to $1 \mathrm{mg} / \mathrm{L}\left(\right.$ as $\mathrm{NO}_{3}-\mathrm{N}$ ) because lower concentrations limit the reproductive capacity of some groundwater bacteria (Rivett et al., 2008). Ca was set at a critical limit of $5 \mathrm{mg} / \mathrm{L}$, because this was the minimum concentration needed for surface freshwater invertebrates to maintain their carapace (Rukke, 2002). For transmissivity, a lower threshold of $52 \mathrm{~m}^{2} / \mathrm{d}$ was set, which was the average transmissivity in Mudstones \& Siltstones (Jones et al., 2000) that typically support depauperate communities (Hahn \& Fuchs, 2009; Johns et al., 2015).

Cave development was considered, because caves provide particularly good groundwater habitats (Culver \& Sket, 2000; Robertson et al., 2009). Physical habitat space was incorporated because it is known to affect faunal distributions. For example, pore space size is known to limit groundwater assemblages by excluding larger invertebrates from habitats (Dole-Olivier et al., 2009).

\section{Calculation}

(a) The ratio of the number of sites above threshold $(A)$ / below threshold $(B)$ was calculated for all parameters $(i)$ in each geo-habitat. The mean of each parameter was ranked between all geo-habitats from 1 (lowest mean) to 11 (highest mean). The threshold ratio for each parameter was multiplied with the rank of its mean $(R m)$ to give a habitat score for each parameter. Values for all parameters were then summed to give an intermediate habitat score (IS, eqn 1).

$$
I S=\sum_{i=1,2,3,4,5}\left(\frac{A}{B} \cdot R m\right)
$$

(b) Each geo-habitat received a cave score (CS) between 1 (no caves) and 4 (extensive caves). Furthermore, geo-habitats either received a penalty score (SP) of 1 (physical space not limiting) or 2 (physical space excluding larger fauna). The IS of each geo-habitat was 
multiplied with the cave score and divided by the space penalty to give the final geo-habitat quality score (FS, eqn 2).

$F S=\frac{I S . C S}{S P}$

\section{Results}

\subsection{Distribution of geo-habitats}

Overall, the total coverage of broad habitat groups varies considerably. Fractured rocks are the most common type of groundwater habitat (62.4\%), whereas karstic (19\%) and porous/ mixed habitats (18.6\%) cover much smaller areas.

The distribution of the 11 geo-habitats is uneven across England and Wales (Fig. 2). Three geo-habitats (Mudstones \& Siltstones, Fractured Sandstone and the Karstic Chalk) clearly dominate, covering areas of $36.9 \%, 20.6 \%$ and $10.7 \%$ respectively. The karstic Chalk forms a continuous band in eastern England, running from north to south (Fig. 2). Conversely, Mudstones \& Siltstones, and Fractured Sandstone have a much more dispersed and patchy distribution (Fig. 2).

Other karstic habitats, such as the Mildly and Moderately Karstic Limestone, are also prevalent across extensive areas of central, southern and eastern England. They form continuous belts running on a north-south axis. Such belts are absent from Wales and south-western England, where Highly Karstic Limestone occurs in isolated patches. Porous and mixed geo-habitats, such as Large-Pore Unconsolidated sediments and Mixed Sandstone are almost entirely restricted to England, and generally have a patchy distribution. An exception are Small-Pore Unconsolidated sediments in eastern England, which are geographically extensive (Fig. 2). Fractured habitats occur widely in Wales, southwest, central and north-west England (Fig. 2). All fractured habitats are relatively discontinuous, but differ greatly in their distribution. Igneous and Metamorphic Rock are relatively uncommon habitats limited to Wales, south-west and northern England. Fractured Sandstone and Mudstones \& Siltstones are widespread.

While some geo-habitats cover extensive areas, others such as Highly Karstic Limestone (2.8 \%), Large-Pore Unconsolidated sediments (1 \%) and Mildly Karstic Limestone ( $1 \%)$ cover only small parts of England and Wales. Overall, the geo-habitats therefore range from widespread and well connected to rare and isolated.

\subsection{Geo-habitat characteristics}

The PCA ordination indicated that geo-habitat was strongly associated with transmissivity (T) (Fig. 3a): Fractured geo-habitats were characterised by low $T$, porous geo-habitats by intermediate $\mathrm{T}$, and karstic geo-habitats by high $\mathrm{T}$ (Fig. 3b). Geo-habitats were clearly distinguishable by broad habitat type (karstic, porous and fractured) on the PCA biplot, with ellipsoids indicating a marginal difference in abiotic conditions between karstic and porous geo-habitats, while showing significant abiotic differences in fractured geo-habitats (Fig. 3c). 
The first principal component axis (15.99\% explained variance) indicated that karstic and porous geo-habitats, grouped on the upper right of the ordination (Fig. 3c), had higher transmissivity, $\mathrm{DOC}, \mathrm{NO}_{3}$ and $\mathrm{Ca}$ than fractured geo-habitats (Fig. 3). The exception was Highly Karstic Limestone, which was separated from the other karstic habitats and had lower concentrations of these parameters.

The second principal component axis (13.78\% explained variance) was characterised by a positive loading of DO (Fig. 3a). Karstic and fractured geo-habitats were characterised by higher DO concentrations than porous geo-habitats (Fig. 3). Again, Highly Karstic Limestone differed from other karstic habitats and had a lower DO concentration. Overall, the PCA confirmed that a broad typology produces distinguishable karstic, porous and fractured groups, but that some geo-habitats do not follow the general patterns.

\section{Hydrogeology}

The geo-habitats had significantly different transmissivity (Kruskal-Wallis test: $H(10)=$ 799.58, $P<0.001$, Fig. 4). The highest mean transmissivities occurred in karstic geo-habitats, such as Moderately Karstic Limestone and the Chalk (1504 m²/d) (Fig. 4, Table 2). Medium transmissivities were found in Mildly Karstic Limestone, Large Pore Unconsolidated and Mixed Sandstone. The lowest transmissivities occurred in two fractured geo-habitats: Igneous Rock $\left(13 \mathrm{~m}^{2} / \mathrm{d}\right)$ and Metamorphic Rock $\left(16 \mathrm{~m}^{2} / \mathrm{d}\right)$. Highly Karstic Limestone had a similar transmissivity to Small-Pore Unconsolidated sediments.

Minimum transmissivities were similar between geo-habitats, ranging between 0.1 and $1.8 \mathrm{~m}^{2} / \mathrm{d}$. Maximum transmissivities varied between 50 and 25,000 $\mathrm{m}^{2} / \mathrm{d}$ (Table 2). Overall, the transmissivity maxima were much lower in fractured geo-habitats than in karstic and porous rocks. Transmissivity was highly variable in all geo-habitats (Fig. 4) and varied over several orders of magnitude in the Chalk (Table 2, Fig. 4). The variability was highest in karstic and porous habitats, and much lower in fractured rocks. The transmissivity in fractured geo-habitats was always low, while karstic and porous habitats had many high transmissivity sites.

Porosity was also significantly different between geo-habitats $(\mathrm{H}(10)=206.5, P<$ 0.001 , Fig. 4). In unconsolidated and mixed habitats, such as Large-Pore, Small-Pore Unconsolidated sediments and Mixed Sandstone the mean porosity was high (>24\%). In contrast, consolidated geo-habitats (except the Chalk; $33.8 \%$ ) had much lower porosity (< $17 \%$ ). With a porosity of $1.5 \%$, Igneous Rock had the lowest recorded value (Fig. 4, Table 2 ).

\section{Hydrochemistry}

DO concentrations differed significantly between geo-habitats $(H(10)=173.43, P<0.001$, Fig. 5). The highest mean DO concentrations occurred in Metamorphic Rock, Igneous Rock and the Chalk. The lowest DO concentrations occurred in Mildly Karstic Limestone, SmallPore Unconsolidated and Large-Pore Unconsolidated sediments. Most porous geo-habitats had lower DO than fractured habitats (Fig. 5, Table 3). Geo-habitats had minimum DO concentrations between 0.02 and $0.5 \mathrm{mg} / \mathrm{L}$, and maximum DO concentrations between 9.3 and $12.6 \mathrm{mg} / \mathrm{L}$.

DOC concentrations also significantly varied between habitats $(H(10)=82.8, P<$ 0.001 , Fig. 5). The highest mean DOC was found in the Chalk and Moderately Karstic Limestone, two karstic habitats, and in Mudstones \& Siltstones (Fig. 5, Table 3). Porous and 
mixed habitats, such as Mixed Sandstone, had intermediate DOC concentrations. DOC was lowest in fractured habitats, such as Igneous Rock and Metamorphic Rock (Fig. 5). Minimum DOC concentrations in geo-habitats ranged between 0.1 to $0.8 \mathrm{mg} / \mathrm{L}$, while the maximum DOC of 292 and 207 mg/L occurred in the Chalk and Moderately Karstic Limestone.

$\mathrm{NO}_{3}$ concentrations were significantly different between geo-habitats $(\mathrm{H}(10)=$ 397.38, $P<0.001$, Fig. 5). The highest mean $\mathrm{NO}_{3}$ concentrations occurred in the Small-Pore Unconsolidated, Large-Pore Unconsolidated and Moderately Karstic Limestone geo-habitats (Fig. 5, Table 3). The lowest $\mathrm{NO}_{3}$ concentrations occurred in fractured geo-habitats, such as Mudstones \& Siltstones and Fractured Sandstone (Fig. 5). Minimum $\mathrm{NO}_{3}$ in habitats ranged between 0.002 to $0.1 \mathrm{mg} / \mathrm{L}$, while the maximum $\mathrm{NO}_{3}$ varied considerably between 12.7 and $72 \mathrm{mg} / \mathrm{L}$.

Ca also varied significantly between habitats $(H(10)=1244.8, P<0.001$, Fig. 5$)$. The highest $\mathrm{Ca}$ concentrations occurred in the Chalk, Moderately Karstic Limestone and LargePore Unconsolidated sediments (Fig. 5, Table 3). The lowest mean Ca concentrations occurred in fractured habitats, such as Igneous Rock and Mudstones \& Siltstones (Fig. 5). Minimum $\mathrm{Ca}$ was fairly consistent between 0.5 and $14.2 \mathrm{mg} / \mathrm{L}$, while maximum $\mathrm{Ca}$ concentrations ranged between 66.2 and $795 \mathrm{mg} / \mathrm{L}$.

\subsection{Geo-habitat quality}

The scores suggest that habitat quality varies considerably among geo-habitats (Fig. 6). The highest quality score was obtained for the Chalk, and the lowest for Metamorphic Rock. For discussion purposes, geo-habitats were assigned to three broad groups with high (> 4.5), intermediate $(4-4.5)$ and low $(<4)$ quality. The high quality group includes the Chalk and Highly Karstic Limestone, two karstic geo-habitats (Fig. 6). The intermediate group includes two karstic (Mildly Karstic Limestone, Moderately Karstic Limestone), one mixed (Mixed Sandstone) and one porous (Large-Pore Unconsolidated) geo-habitat (Fig. 6). The low quality group comprises one porous geo-habitat (Small-Pore Unconsolidated) and the fractured geo-habitats (Mudstones \& Siltstones, Igneous Rock, Fractured Sandstone, Metamorphic Rock) (Fig. 6).

The distribution map with habitats grouped according to their quality shows that low quality habitats are dominant in Wales, northern and south-west England (Fig. 7). High quality, and some medium quality, habitats provide highly permeable corridors connecting southern to northern England. Medium quality habitats cover small geographical areas and are spatially patchy, particularly in Wales and southern England.

\section{Discussion}

\subsection{Assessing the new typology}

In this study the classical approach of dividing habitats into karstic, porous and fractured rocks was refined to produce a higher resolution typology of 11 geo-habitats. These geohabitats differ significantly in their hydrogeological and hydrochemical characteristics, supporting this typology. The differences are likely to influence groundwater communities (Gibert et al., 1994; Datry et al., 2005; Hahn, 2006; Schmidt \& Hahn, 2012), illustrating the 
advantage of this higher resolution. However, all abiotic parameters remain highly variable within geo-habitats, reflecting geological heterogeneity. The transmissivity variability and resource patchiness are likely to be the cause of the uneven distribution of groundwater fauna observed in many studies (Gibert et al., 1994; Datry et al., 2005). For example, preferential flowpaths at the scale of $10^{-2}-10^{2}$ metres may determine the oxygen and food supply for microbes and metazoans in rocks (Stanford et al., 1994; Harvey, 1997; Larned, 2012). Therefore, even more detailed geological data are needed to explain faunal distributions in regional-scale and local-scale studies.

While high geological resolution is important, grouping of similar habitat types is necessary because it is impossible to sample 100's of habitats individually. Any habitat typology needs to balance grouping with capturing habitat differences that are relevant to organisms. For a national scale study, the standard habitat groups (karstic, porous, fractured) may be too coarse to accurately assess habitat suitability. For example, fractured Igneous Rock in south-west England supports complex ecological communities, including frequent occurrences of the endemic Niphargus glenniei (Knight, 2009; Johns et al., 2015). In contrast, stygobites are much scarcer in Fractured Sandstone (Weitowitz, 2017). Combining fractured rocks into a single habitat category (e.g. in Hahn \& Fuchs, 2009; Cornu et al., 2013) means that substantial differences in habitat are overlooked. At the national scale, 11 geo-habitats appear to be a good compromise of feasibility and resolution, and a similar typology could be used in other geographical areas.

\subsection{Geo-habitat characteristics and quality}

Although porosity is important in determining space provision and nutrient delivery in unconsolidated habitats (Hahn, 2006; Hahn \& Fuchs, 2009), it is a poor proxy of habitat quality. For example, the Chalk has a high mean porosity of $34 \%$ (Allen et al., 1997), but groundwater fauna are too large to live in its small pore spaces (median $0.49 \mu \mathrm{m}$; Price et al., 1976). Pore space size is more important in unconsolidated sediments, determining both physical space and permeability. However, even in porous rocks, high porosity does not necessarily reflect high habitat quality. For example, some Small-Pore Unconsolidated sediments (e.g. clays) may have a similar porosity to Large-Pore Unconsolidated sediments (e.g. gravels), yet the effective porosity contributing to fluid flow may be almost zero (Ezekwe, 2010), and the void spaces too small to provide a habitat.

Transmissivity provides a better habitat quality proxy because it integrates habitat information on multiple scales. It influences habitat chemistry (Hahn, 2006; Hahn \& Fuchs, 2009; Robertson et al., 2009), and reflects fracture and fissure size, frequency and connectivity. However, transmissivity data are obtained from borehole tests and therefore in karst aquifers where caves are the best habitat, it may be a poor indicator of habitat quality. For example, the Highly Karstic Limestone harbours abundant groundwater assemblages in extensive cave systems in England and Wales (Robertson et al., 2009; Knight, 2011; Johns et al., 2015), but has a relatively low mean borehole transmissivity $\left(317 \mathrm{~m}^{2} / \mathrm{d}\right)$. Furthermore, transmissivity is only measured in successful abstraction boreholes, biasing available data to the more permeable sections of aquifers (Allen et al., 1997). The overall habitat quality depends on how extensive and connected the more transmissive areas are. 
Future studies could consider the number, yield and distribution of abstraction points in specific geologies, as these may reflect the extent of high quality habitat patches.

Although more permeable rocks generally have higher levels of oxygen and nutrients (Hahn \& Fuchs, 2009), this was not always the case in the geo-habitats. While the water chemistry data are probably representative for most geo-habitats, there may be some sampling biases. For example, it is likely that the low mean DOC in Highly Karstic Limestone was due to water chemistry being measured in boreholes rather than caves, with DOC being considerably higher in the latter (e.g. up to $4 \mathrm{mg} / \mathrm{L}$, Simon et al., 2007; Ban et al., 2008). The mean DO in Mildly Karstic Limestone was relatively low, probably due to samples from anoxic boreholes confined by low permeability overlying strata (Allen et al., 1997). The high DO concentrations in Metamorphic and Igneous Rock may reflect a sampling bias towards shallow, unconfined sources, rather than a widespread occurrence of high DO throughout these geo-habitats.

However, the high mean DO in Metamorphic and Igneous Rock, and the high mean DOC in Mudstones \& Siltstones suggest that these geo-habitats contain at least some fracture networks with conditions that are likely to be suitable for groundwater fauna, even though these geologies are generally regarded as poor habitats (Cornu et al., 2013) and barriers to dispersal (Johns et al., 2015). An analysis of stygobite distribution data showed that four of the eight stygobite species in England and Wales occur in Mudstones \& Siltstones, although occurrences were extremely low and sometimes limited to a single record (Weitowitz, 2017).

Every geo-habitat in England and Wales should have the potential to support complex groundwater communities in places, as the mean hydrochemical conditions are above currently known thresholds for groundwater ecosystems (see Rukke, 2002; Datry et al., 2005; Hahn, 2006). The differences in habitat quality are most likely determined by the frequency and extent of poor quality habitat patches, also limiting dispersal. Geo-habitat areas with minimum transmissivities below $2 \mathrm{~m}^{2} / \mathrm{d}$, and DO and DOC concentrations below $1 \mathrm{mg} / \mathrm{l}$ and $0.4 \mathrm{mg} / \mathrm{l}$ respectively, are likely to harbour fewer invertebrates (Malard \& Hervant, 1999) and lower biodiversity (Datry et al., 2005). Taking habitat patchiness into account appears to be crucial in developing new habitat typologies, assessing habitat quality and understanding species distributions. However, due to the data bias towards more permeable aquifer sections, and the high degree of aquifer heterogeneity, this remains challenging.

Given the importance of the included abiotic parameters to groundwater ecosystems, the geo-habitat quality scores are expected to relate to resident community complexity. Low quality geo-habitats should harbour lower species diversity and abundance than high quality geo-habitats. Although the proposed typology is yet to be validated with ecological data, the quality scores are mostly in agreement with biological data from similar habitat types. The Chalk and the Highly Karstic Limestone, the best geo-habitats, are known to harbour significant proportions of the UK groundwater biodiversity (Arietti \& Edwards, 2006; Johns et al., 2015; Maurice et al., 2015). Fractured geo-habitats were grouped as low quality habitats and are typically characterised by less diverse communities (Hahn \& Matzke, 2005; Hahn \& Fuchs, 2009; Johns et al., 2015). However, there are clear quality differences between fractured geo-habitats. Igneous Rock, previously classified as unsuitable (Cornu et al., 2013), scored considerably higher than other fractured geo-habitats 
(e.g. Metamorphic Rock, Fractured Sandstone), which is supported by the significant faunal assemblages (including the endemic $N$. glenniei) found there (Johns et al., 2015). Small-Pore Unconsolidated sediments were classified as a low quality geo-habitat, although porous aquifers harbour high biodiversity elsewhere (e.g. Eberhard et al., 2005; Castellarini et al., 2007; Griebler et al., 2010). In Small-Pore Unconsolidated sediments, grains only range between 0.06-0.25 $\mathrm{mm}$ in fine sands and up to $2 \mathrm{~mm}$ in coarse sands (Wentworth, 1922), with pore spaces likely excluding all larger metazoans (e.g. Dole-Olivier et al., 2009).

While the geo-habitat scores account for the relative proportion of good and bad habitat patches, the chemical requirements of many groundwater organisms, particularly critical thresholds, are not well known (Larned, 2012). More research is needed to determine their abiotic requirements and to develop methods of incorporating geological heterogeneity in habitat assessments.

\subsection{Distribution of geo-habitats}

The low connectivity of groundwater habitats is a key control on faunal distributions, causing them to remain static for long periods of time (Culver et al., 2009; Galassi et al., 2009; Robertson et al., 2009; Johns et al., 2015). In England and Wales, most complex groundwater ecosystems are likely to occur in karstic or porous geo-habitats (except for Small-Pore Unconsolidated sediments). Whilst karstic geo-habitats in this region all harbour abundant stygofauna, communities in porous and mixed habitats seem to be more limited (Robertson et al., 2009; Johns et al., 2015; Weitowitz, 2017). The highly transmissive karstic belts in south-east England should facilitate the north-south dispersal of species. Nevertheless, many species remain absent from northern England, which is thought to be due to the impacts of the Devensian glaciation (Proudlove et al., 2003; Robertson et al., 2009; Maurice et al., 2015), and suggests low dispersal rates even within these connected aquifers.

Fig. 7 shows that over $60 \%$ of England and Wales is covered by low quality fractured geo-habitats, interspersed between the smaller outcrops of karstic rocks. These extensive outcrops of less suitable habitats are likely to have substantial ecological significance. They have been shown to harbour lower species diversity and abundance (Johns et al., 2015; Weitowitz, 2017), and are likely to limit species dispersal, particularly on the east-west axis. For example, the endemic $N$. glenniei may remain limited to Igneous and Metamorphic Rock in south-west England by a barrier of Mudstones \& Siltstones, preventing dispersal to central England (Johns et al., 2015).

Hyporheic zones and some of the more permeable superficial deposits (e.g. alluvium and river terrace deposits in south-west England; Smedley \& Allen, 2004) are likely to provide important additional habitats for groundwater organisms. For example, they may have facilitated the dispersal of $N$. aquilex, which has a much wider distribution than other UK stygobite species (Ward \& Palmer, 1994; Robertson et al., 2009; Johns et al., 2015). These habitats were not considered in the analysis, because little hydrogeological information and no chemistry data are available for them. 


\section{Conclusion}

This paper developed a new national-scale habitat typology for England and Wales, in which 11 geo-habitats were defined. These had significantly different hydrogeological and hydrochemical characteristics, validating the categorisation and suggesting this may be an appropriate number of habitats for national-scale evaluations. The considerable withinhabitat variation illustrates the heterogeneity of groundwater habitats, and the need for even higher resolution hydrogeological data in regional and local groundwater ecosystem surveys. The use of thresholds and habitat quality scores may be useful for assessing habitats in other areas, and could be applied at local, regional and national scales.

Substantial parts of England and Wales are covered by low quality, mainly fractured, geo-habitats that provide limited physical space and little connectivity. This may result in reduced biodiversity in comparison to other countries that have more extensive areas of good quality habitats. The more complex ecosystems are likely to occur in the higher quality habitats, which should receive prioritised attention in conservation. However, low quality habitats may be important locally. For example, the Igneous Rock geo-habitat in south-west England harbours the endemic N. glenniei.

This habitat typology provides a framework for ecosystem evaluation in England and Wales, which needs to be tested using ecological data. Similar typologies could be used as a framework for evaluating groundwater ecosystems in other geographic regions.

\section{Acknowledgments}

Damiano Weitowitz was supported by a joint studentship of the National Environment Research Council (NERC) and the University of Roehampton, London. The authors wish to thank the Environment Agency (EA) and the British Geological Survey (BGS) for the provision of hydrogeological and hydrochemical data. This paper is published with the permission of the Director of the British Geological Survey.

\section{References}

Allen D, Brewerton L, Coleby L, Gibbs B, Lewis M, MacDonald A, Wagstaff SJ, Williams AT (1997) The physical properties of major aquifers in England and Wales. British Geological Survey technical report WD/97/34, Environment Agency R\&D publication 8

Ander EL, Shand P, Griffiths K, Lawrence A, Hart P, Pawley J (2004) Baseline report series. 13: The Great Ouse chalk aquifer, East Anglia. Environment Agency

Arietti M, Edwards B (2006) Groundwater Invertebrates in chalk boreholes and their significance in public water supply. Internal report for Three Valleys Water

Atkinson T, Smart P (1981) Artificial tracers in hydrogeology. London: Royal Society

Bloomfield JP, Jackson CR, Stuart ME (2013) Changes in groundwater levels, temperature and quality in the UK over the $20^{\text {th }}$ century: An assessment of evidence of impacts from climate change, Hydrol and Earth Syst. Sci. 17: 4769-4787 
Bork J, Berkhoff SE, Bork S, Hahn HJ (2009) Using subsurface metazoan fauna to indicate groundwater-surface water interactions in the Nakdong river floodplain, South Korea, Hydrogeology J. 17(1): 61-75

Boulton AJ, Fenwick GD, Hancock PJ, \& Harvey MS (2008) Biodiversity, functional roles and ecosystem services of groundwater invertebrates. Invertebr. Systematics, 22(2): 103-116

British Geological Survey (2016)

http://www.bgs.ac.uk/research/groundwater/quality/BaselineUK/baselineEngWales.html

Cited 18 September 2016

Cañadas A, Sagarminaga R, De Stephanis R, Urquiola E, Hammond P (2005) Habitat preference modelling as a conservation tool: Proposals for marine protected areas for cetaceans in southern Spanish waters, Aquat. Conserv.: Mar. and Freshw. Ecosyst. 15(5): 495-521

Castellarini F, Malard F, Dole-Olivier M, Gibert J (2007) Modelling the distribution of stygobionts in the Jura mountains (eastern France): Implications for the protection of ground waters, Divers. and Distrib. 13(2): 213-224

Cobbing J, Moreau M, Shand P, Lancaster A (2004) Baseline report series. 14: The Corallian of Oxfordshire and Wiltshire. Environment Agency

Cornu J, Eme D, Malard F (2013) The distribution of groundwater habitats in Europe, Hydrogeol. J. 21(5): 949-960

Culver DC, Sket B (2000) Hotspots of subterranean biodiversity in caves and wells, J. of Cave and Karst Stud. 62(1): 11-17

Culver DC, Pipan T, Schneider K (2009) Vicariance, dispersal and scale in the aquatic subterranean fauna of karst regions, Freshw. Biol. 54(4): 918-929

Danielopol DL, Gibert J, Griebler C, Gunatilaka A, Hahn HJ, Messana G, Notenboom J, Sket, B (2004) Incorporating ecological perspectives in European groundwater management policy, Environ. Conserv. 31(3): 185-189

Datry T, Malard F, Gibert J (2005) Response of invertebrate assemblages to increased groundwater recharge rates in a phreatic aquifer, J of the North Am. Benthol. Soc. 24(3): 461-477

Di Lorenzo T, Galassi DM (2013) Agricultural impact on mediterranean alluvial aquifers: Do groundwater communities respond?, Fundam. and Appl. Limnol. 182(4): 271-282

Dole-Olivier M, Malard F, Martin D, Lefébure T, Gibert J (2009) Relationships between environmental variables and groundwater biodiversity at the regional scale, Freshw. Biol. 54(4): 797-813 
Eberhard S, Halse S, Humphreys W (2005) Stygofauna in the Pilbara region, north-west Western Australia: A review, J. of the R. Soc. of West. Aust. 88(4): 167-176

ESRI (2011) ArcGIS Desktop: Release 10, Environmental Systems Research Institute. Redlands, California, United States.

Ezekwe N (2010) Petroleum reservoir engineering practice. Prentice Hall

Finston TL, Johnson MS (2004) Geographic patterns of genetic diversity in subterranean amphipods of the Pilbara, Western Australia, Mar. and Freshw. Res. 55(6): 619-628

Foster S, Tyson G, Colvin C, Wireman M, Manzano M, Kreamer D, Goldscheider N, Coxon C (2016) Strategic overview series: Ecosystem conservation \& groundwater, International Association of Hydrogeologists, https://iah.org/wp-content/uploads/2016/04/IAH-SOSEcosystem-Conservation-Groundwater-9-Mar-2016.pdf. Cited 20 February 2017

Gagic V, Petrović-Obradović O, Fründ J, Kavallieratos NG, Athanassiou CG, Starý P, Tomanović Ž (2016) The effects of aphid traits on parasitoid host use and specialist advantage, PloS One 11(6): 1-14

Galassi DMP, Stoch F, Fiasca B, Di Lorenzo T, Gattone E (2009) Groundwater biodiversity patterns in the Lessinian Massif of northern Italy, Freshw. Biol. 54(4): 830-847

Gibert J, Danielopol D, Stanford JA (1994) Groundwater ecology. Academic Press

Gibert J, Culver DC, Dole-Olivier M, Malard F, Christman MC, Deharveng L (2009) Assessing and conserving groundwater biodiversity: Synthesis and perspectives, Freshw. Biol. 54(4): 930-941

Goldscheider N, Hunkeler D, Rossi P (2006) Review: Microbial biocenoses in pristine aquifers and an assessment of investigative methods, Hydrogeol. J. 14(6): 926-941

Griebler C, Stein H, Kellermann C, Berkhoff S, Brielmann H, Schmidt S, Selesi D, Steube C, Fuchs A, Hahn HJ (2010) Ecological assessment of groundwater ecosystems - Vision or illusion?, Ecol. Eng. 36(9): 1174-1190

Griffiths KJ, Shand P, Marchant P (2006) Baseline report series. 23: The Lincolnshire Limestone. Environment Agency

Hahn HJ, Matzke D (2005) A comparison of stygofauna communities inside and outside groundwater bores, Limnol. 35(1): 31-44

Hahn HJ (2006) The GW-fauna-index: A first approach to a quantitative ecological assessment of groundwater habitats, Limnol. 36(2): 119-137

Hahn, HJ (2009) A proposal for an extended typology of groundwater habitats, Hydrogeol. J. 17(1): 77-81 
Hahn HJ, Fuchs A (2009) Distribution patterns of groundwater communities across aquifer types in south-western Germany, Freshw. Biol. 54(4): 848-860

Hancock PJ, Boulton AJ, Humphreys WF (2005) Aquifers and hyporheic zones: Towards an ecological understanding of groundwater, Hydrogeol. J. 13(1): 98-111

Harvey RW (1997) Microorganisms as tracers in groundwater injection and recovery experiments: A review, FEMS Microbiol. Rev. 20(3): 461-472

HCRS (2016) Hypogean Crustacea Recording Scheme: http://hcrs.freshwaterlife.org/ Cited 22 August 2016

Johns T, Jones JI, Knight L, Maurice L, Wood P, Robertson A (2015) Regional-scale drivers of groundwater faunal distributions, Freshw. Sci. 34(1): 316-328

Jones $\mathrm{H}$, Morris B, Cheney C, Brewerton L, Merrin P, Lewis M, MacDonald AM, Coleby LM, Talbot JC, Mckenzie AA, Bird MJ, Cunningham JE, Robinson V (2000) The physical properties of minor aquifers in England and Wales. British Geological Survey technical report WD/00/04, Environment Agency R\&D publication 68

Josse J, Husson F (2012) Handling missing values in exploratory multivariate data analysis methods, J. de la Soc. Fr. de Stat. 153(2): 79-99

Josse J, Husson $F(2016)$ missMDA: A package for handling missing values in multivariate data analysis, J of Stat. Softw. 70(1): 1-31

Klove B, Ala-aho P, Bertrand G, Boukalova Z, Ertuerk A, Goldscheider N, Ilmonen J, Karakaya $\mathrm{N}$, Kupfersberger $\mathrm{H}$, Kvoerner J, Lundberg A, Mileusnic M, Moszczynska A, Muotka T, Preda E, Rossi P, Siergieiev D, Simek J, Wachniew P, Angheluta V, Widerlund A (2011) Groundwater dependent ecosystems. Part I: Hydroecological status and trends, Environ. Sci. Policy 14(7): 770-781

Knight L (2009) The biodiversity action plan (BAP) for Niphargus glenniei (Crustacea: Amphipoda: Niphargidae): The first British troglobite to be listed, Cave and Karst Sci. 35(1): 13-18

Knight LRFD (2011) The aquatic macro-invertebrate fauna of Swildon's Hole, Mendip Hills, Somerset, UK, Cave and Karst Sci. 38(2): 81-92

Larned ST (2012) Phreatic groundwater ecosystems: Research frontiers for freshwater ecology, Freshw. Biol. 57(5): 885-906

Lefébure T, Douady C, Malard F, Gibert J (2007) Testing dispersal and cryptic diversity in a widely distributed groundwater amphipod (Niphargus rhenorhodanensis), Mol. Phylogenet. and Evol. 42(3): 676-686

Malard F, Hervant F (1999) Oxygen supply and the adaptations of animals in groundwater, Freshw. Biol. 41(1): 1-30 
Malard F, Boutin C, Camacho Al, Ferreira D, Michel G, Sket B, Stoch F (2009) Diversity patterns of stygobiotic crustaceans across multiple spatial scales in Europe, Freshw. Biol. 54(4): $756-776$

Martin P, de Broyer C, Fiers F, Michel G, Sablon, R, Wouters K (2009) Biodiversity of Belgian groundwater fauna in relation to environmental conditions, Freshw. Biol. 54(4): 814-829

Mattison RG, Taki H, Harayama S (2002) The bacterivorous soil flagellate Heteromita globosa reduces bacterial clogging under denitrifying conditions in sand-filled aquifer columns, Appl. and Environ. Microbiol. 68(9): 4539-4545

Mattison R, Taki H, Harayama S (2005) The soil flagellate Heteromita globosa accelerates bacterial degradation of alkylbenzenes through grazing and acetate excretion in batch culture, Microb. Ecol. 49(1): 142-150

Maurice L, Atkinson T, Barker JA, Bloomfield J, Farrant A, Williams A (2006) Karstic behaviour of groundwater in the English Chalk, J. of Hydrol. 330(1): 63-70

Maurice L (2009) Investigations of Rapid Groundwater Flow and Karst in the Chalk. Doctoral thesis, University College LondonMaurice L, Bloomfield J (2012) Stygobitic invertebrates in groundwater - A review from a hydrogeological perspective, Freshw. Rev. 5(1): 51-71

Maurice L, Atkinson T, Barker J, Williams A, Gallagher A (2012) The nature and distribution of flowing features in a weakly karstified porous limestone aquifer, J. of Hydrol. 438: 3-15

Maurice L, Robertson A, White D, Knight L, Johns T, Edwards F, Arietti M, Sorensen JPR, Weitowitz D, Marchant BP, Bloomfield JP (2015) The invertebrate ecology of the Chalk aquifer in England (UK), Hydrogeol. J. 24(2): 459-474

Mclnerney CE, Maurice L, Robertson AL, Knight LR, Arnscheidt J, Venditti C, Dooley JSG, Mathers T, Matthijs S, Eriksson K, Proudlove GS, Hänfling B (2014) The ancient Britons: Groundwater fauna survived extreme climate change over tens of millions of years across NW Europe, Mol. Ecol. 23(5): 1153-1166

Price M, Bird M, Foster S (1976) Chalk pore-size measurements and their significance, Water Serv. 80(968): 596-600

Proudlove GS, Wood PJ, Harding PT, Horne DJ, Gledhill T, Knight LRFD (2003) A review of the status and distribution of the subterranean aquatic Crustacea of Britain and Ireland, Cave and Karst Sci. 30(2): 51-74

RDC Team (2017) A language and environment for statistical computing, R Development Core Team

Revelle, W. (2016) psych: Procedures for personality and psychological research, Northwestern University, Evanston, Illinois, USA, http://CRAN.R-project.org/package=psych, Version $=1.6 .4$ 
Rivett MO, Buss SR, Morgan P, Smith JWN, Bemment CD (2008) Nitrate attenuation in groundwater: A review of biogeochemical controlling processes, Water Res. 42(16): 42154232

Robertson A, Smith J, Johns T, Proudlove G (2009) The distribution and diversity of stygobites in Great Britain: An analysis to inform groundwater management, Q. J. of Eng. Geol. and Hydrogeol. 42(3): 359-368

Rukke N (2002) Effects of low calcium concentrations on two common freshwater crustaceans, Gammarus lacustris and Astacus astacus, Funct. Ecol. 16(3): 357-366

Russ J, Montgomery W (2002) Habitat associations of bats in northern Ireland: Implications for conservation, Biol. Conserv. 108(1): 49-58

Russo D, Almenar D, Aihartza J, Goiti U, Salsamendi E, Garin I (2005) Habitat selection in sympatric Rhinolophus mehelyi and R. euryale (Mammalia: Chiroptera), J. of Zool. 266(3): 327-332

Schmidt SI, Hahn HJ (2012) What is groundwater and what does this mean to fauna?, Limnol. 42(1): 1-6

Shand P, Haria AH, Neal C, Griffiths K, Gooddy D, Dixon AJ, Hill T, Buckley DK, Cuningham J (2005) Hydrochemical heterogeneity in an upland catchment: Further characterisation of the spatial, temporal and depth variations in soils, streams and groundwaters of the Plynlimon forested catchment, Wales, Hydrol. and Earth Syst. Sciences 9(6): 621-644

Smedley P, Griffiths K, Tyler-Whittle R, Hargreaves R, Lawrence AR, Besien T (2003) Baseline report series. 5: The Chalk of the North Downs, Kent and East Surrey. Environment Agency

Smedley P, Neumann I, Farrell R (2004) Baseline report series. 10: The Chalk aquifer of Yorkshire and North Humberside. Environment Agency

Smedley P, Allen D (2004) Baseline report series. 16: The granites of south-west England. Environment Agency

Smith, A, Myers AH, Armstrong RW, Daley DL (2013) User guide for the BGS DiGMapGB-50 data (V7). British Geological Survey

Stanford J, Ward J, Ellis B (1994) Ecology of the alluvial aquifers of the flathead river, Montana. In: Gibert J, Danielopol DL, Stanford JA (ed) Groundwater ecology. p 367-388

Stein H, Kellermann C, Schmidt SI, Brielmann H, Steube C, Berkhoff SE, Fuchs A, Hahn HJ, Thulin B, Griebler C (2010) The potential use of fauna and bacteria as ecological indicators for the assessment of groundwater quality, J. of Environ. Monit. 12(1): 242-254

Stein H, Griebler C, Berkhoff S, Matzke D, Fuchs A, Hahn HJ (2012) Stygoregions - A promising approach to a bioregional classification of groundwater systems, Scientific Reports, 2: 1-9 
Stoch F, Artheau M, Brancelj A, Galassi, DM, F (2009) Biodiversity indicators in European ground waters: Towards a predictive model of stygobiotic species richness, Freshw. Biol. 54(4): 745-755

Tomlinson M, Boulton AJ (2010) Ecology and management of subsurface groundwater dependent ecosystems in Australia - A review, Mar. and Freshw. Res. 61(8): 936-949

VLMP (2016) Maximum dissolved oxygen concentration saturation table, Maine Volunteer Lake Monitoring Program:

http://www.mainevlmp.org/wp-content/uploads/2014/01/Maximum-Dissolved-OxygenConcentration-Saturation-Table.pdf. Cited $6^{\text {th }}$ October 2016

Ward J, Palmer M (1994) Distribution patterns of interstitial freshwater meiofauna over a range of spatial scales, with emphasis on alluvial river-aquifer systems, Hydrobiol. 287(1): 147-156

Weitowitz DC (2017) An investigation into the distribution of groundwater animals (stygobites) in England and Wales. Unpublished PhD thesis, University of Roehampton

Wentworth CK (1922) A scale of grade and class terms for clastic sediments, The J. of Geol. 30 (5): $377-392$

Worthington S, Ford D (2009) Self-organized permeability in carbonate aquifers, Groundw. 47(3): 326-336 


\section{Tables}

Table 1: Summary of the main lithologies and geological formations contained within each geo-habitat and their geological age range. Geological periods from which most units in a geo-habitat are derived from are marked in italic.

\begin{tabular}{|c|c|c|}
\hline Geo-Habitat & $\begin{array}{l}\text { Some of main lithologies and formations } \\
\text { contained }\end{array}$ & Geological periods \\
\hline Karstic Chalk & All chalk & Cretaceous \\
\hline Mildly Karstic Limestone & Limestone, dolostones & Permian \\
\hline Moderately Karstic Limestone & Oolite, Corallian limestones & Jurassic - Cretaceous \\
\hline Highly Karstic Limestone & $\begin{array}{l}\text { Limestone, calcarenite, dolomitised limestone, } \\
\text { dolostones }\end{array}$ & $\begin{array}{l}\text { Neoproterozoic - } \\
\text { Carboniferous }\end{array}$ \\
\hline Small-Pore Unconsolidated & Clay, sand, sand + clay, mud, silt & Cretaceous - Quaternary \\
\hline Large-Pore Unconsolidated & Gravel, sand + gravel & Cretaceous - Quaternary \\
\hline Mixed Sandstone & $\begin{array}{c}\text { Sherwood Sandstone Group, Kinnerton } \\
\text { Sandstone Formation, Tunbridge Wells Sand } \\
\text { Formation }\end{array}$ & $\begin{array}{l}\text { Permo-Triassic- } \\
\text { Cretaceous }\end{array}$ \\
\hline Fractured Sandstone & $\begin{array}{l}\text { Old Red Sandstone, Crackington Formation, } \\
\text { Millstone Grit, wacke }\end{array}$ & Neoproterozoic - Jurassic \\
\hline Igneous Rock & Andesite, basalt, gabbro, granite, lava, tuff & $\begin{array}{l}\text { Neoproterozoic - } \\
\text { Permian }\end{array}$ \\
\hline Metamorphic Rock & Gneiss, mylonite, quartzite, schist, slate & Neoproterozoic - Triassic \\
\hline Mudstones \& Siltstones & $\begin{array}{l}\text { Aylesbeare Mudstone Group, Mercia } \\
\text { Mudstone Group }\end{array}$ & $\begin{array}{l}\text { Neoproterozoic - } \\
\text { Cretaceous }\end{array}$ \\
\hline
\end{tabular}


Table 2: Number of samples, mean values, standard errors (SE), minimum (Min) and maximum (Max) values of transmissivity and porosity for each of the geo-habitats. Arrows indicate significantly higher $\uparrow$ or lower $\downarrow$ levels of a parameter than the 'control' (in italic) geo-habitat (Igneous Rock) according to multiple pairwise comparisons (Bonferroni corrected).

Geo-Habitat Transmissivity $\left(\mathrm{m}^{2} / \mathrm{d}\right)$

\begin{tabular}{|c|c|c|c|c|c|c|c|c|}
\hline & $\begin{array}{l}\text { Number } \\
\text { of Sites }\end{array}$ & Mean (SE) & Min & Max & $\begin{array}{c}\text { Number of } \\
\text { Sites }\end{array}$ & Mean (SE) & Min & Max \\
\hline Chalk & 734 & $1504.2(91.1) \uparrow$ & 0.5 & 25000 & 80 & $33.8(0.9) \mathbf{4}$ & 14 & 47.8 \\
\hline $\begin{array}{l}\text { Mildly Karstic } \\
\text { Limestone }\end{array}$ & 22 & $502.7(160.6) \uparrow$ & 0.4 & 2800 & 5 & $13.5(2)$ & 9.5 & 19.7 \\
\hline $\begin{array}{l}\text { Moderately } \\
\text { Karstic Limestone }\end{array}$ & 82 & $1628.8(317.6) \uparrow$ & 0.5 & 14000 & 25 & $17.1(0.7)$ & 8.1 & 25.8 \\
\hline $\begin{array}{l}\text { Highly Karstic } \\
\text { Limestone }\end{array}$ & 33 & $317.4(178.7) \uparrow$ & 0.1 & 5900 & 15 & $4.9(1.6)$ & 0.3 & 19.5 \\
\hline $\begin{array}{c}\text { Small-Pore } \\
\text { Unconsolidated }\end{array}$ & 40 & $252.1(85.4) \hat{\top}$ & 1.1 & 2300 & 4 & $27.2(3.7) \hat{\uparrow}$ & 17.1 & 32.8 \\
\hline $\begin{array}{c}\text { Large-Pore } \\
\text { Unconsolidated }\end{array}$ & 86 & $581.5(53)$ & 1.8 & 2500 & 1 & 53.7 (NA) $\uparrow$ & 53.7 & 53.7 \\
\hline Mixed Sandstone & 320 & $505.6(41.7) \uparrow$ & 1.7 & 6200 & 328 & $24.5(0.4) \uparrow$ & 4.3 & 52.9 \\
\hline $\begin{array}{l}\text { Fractured } \\
\text { Sandstone }\end{array}$ & 147 & $111.9(21)$ & 0.1 & 1800 & 21 & $13.2(1.1)$ & 5.3 & 21.4 \\
\hline Igneous Rock & 13 & $13.4(4.7)$ & 0.1 & 50 & 4 & $1.5(0.9)$ & 0.4 & 4.1 \\
\hline $\begin{array}{l}\text { Metamorphic } \\
\text { Rock }\end{array}$ & 71 & 16.1 (3.9) & 0.1 & 180 & 0 & NA & NA & NA \\
\hline $\begin{array}{c}\text { Mudstones \& } \\
\text { Siltstones }\end{array}$ & 176 & $51.7(9.2)$ & 0.2 & 1300 & 35 & $16.1(1.4)$ & 2.3 & 32.8 \\
\hline
\end{tabular}

\begin{tabular}{|c|c|c|c|c|c|c|c|c|}
\hline & $\begin{array}{l}\text { Number } \\
\text { of Sites }\end{array}$ & Mean (SE) & Min & Max & $\begin{array}{c}\text { Number of } \\
\text { Sites }\end{array}$ & Mean (SE) & Min & Max \\
\hline Chalk & 734 & $1504.2(91.1) \boldsymbol{\varphi}$ & 0.5 & 25000 & 80 & $33.8(0.9) \mathbf{A}$ & 14 & 47.8 \\
\hline $\begin{array}{l}\text { Mildly Karstic } \\
\text { Limestone }\end{array}$ & 22 & $502.7(160.6) \boldsymbol{A}$ & 0.4 & 2800 & 5 & $13.5(2)$ & 9.5 & 19.7 \\
\hline $\begin{array}{c}\text { Moderately } \\
\text { Karstic Limestone }\end{array}$ & 82 & $1628.8(317.6) \boldsymbol{\top}$ & 0.5 & 14000 & 25 & $17.1(0.7)$ & 8.1 & 25.8 \\
\hline $\begin{array}{l}\text { Highly Karstic } \\
\text { Limestone }\end{array}$ & 33 & $317.4(178.7) \uparrow$ & 0.1 & 5900 & 15 & $4.9(1.6)$ & 0.3 & 19.5 \\
\hline $\begin{array}{c}\text { Small-Pore } \\
\text { Unconsolidated }\end{array}$ & 40 & $252.1(85.4) \boldsymbol{\uparrow}$ & 1.1 & 2300 & 4 & $27.2(3.7) \boldsymbol{\uparrow}$ & 17.1 & 32.8 \\
\hline $\begin{array}{c}\text { Large-Pore } \\
\text { Unconsolidated }\end{array}$ & 86 & $581.5(53)$ & 1.8 & 2500 & 1 & 53.7 (NA) $\hat{\top}$ & 53.7 & 53.7 \\
\hline Mixed Sandstone & 320 & $505.6(41.7) \boldsymbol{\top}$ & 1.7 & 6200 & 328 & $24.5(0.4) \hat{\top}$ & 4.3 & 52.9 \\
\hline $\begin{array}{l}\text { Fractured } \\
\text { Sandstone }\end{array}$ & 147 & $111.9(21)$ & 0.1 & 1800 & 21 & $13.2(1.1)$ & 5.3 & 21.4 \\
\hline Igneous Rock & 13 & $13.4(4.7)$ & 0.1 & 50 & 4 & $1.5(0.9)$ & 0.4 & 4.1 \\
\hline $\begin{array}{c}\text { Metamorphic } \\
\text { Rock }\end{array}$ & 71 & $16.1(3.9)$ & 0.1 & 180 & 0 & NA & NA & NA \\
\hline $\begin{array}{l}\text { Mudstones \& } \\
\text { Siltstones }\end{array}$ & 176 & $51.7(9.2)$ & 0.2 & 1300 & 35 & $16.1(1.4)$ & 2.3 & 32.8 \\
\hline
\end{tabular}
Sites

Porosity (\%)

\begin{tabular}{|c|c|c|c|c|c|c|c|c|}
\hline & $\begin{array}{l}\text { Number } \\
\text { of Sites }\end{array}$ & Mean (SE) & Min & Max & $\begin{array}{c}\text { Number of } \\
\text { Sites }\end{array}$ & Mean (SE) & Min & Max \\
\hline Chalk & 734 & $1504.2(91.1) \uparrow$ & 0.5 & 25000 & 80 & $33.8(0.9) \mathbf{4}$ & 14 & 47.8 \\
\hline $\begin{array}{l}\text { Mildly Karstic } \\
\text { Limestone }\end{array}$ & 22 & $502.7(160.6) \uparrow$ & 0.4 & 2800 & 5 & $13.5(2)$ & 9.5 & 19.7 \\
\hline $\begin{array}{l}\text { Moderately } \\
\text { Karstic Limestone }\end{array}$ & 82 & $1628.8(317.6) \uparrow$ & 0.5 & 14000 & 25 & $17.1(0.7)$ & 8.1 & 25.8 \\
\hline $\begin{array}{l}\text { Highly Karstic } \\
\text { Limestone }\end{array}$ & 33 & $317.4(178.7) \uparrow$ & 0.1 & 5900 & 15 & $4.9(1.6)$ & 0.3 & 19.5 \\
\hline $\begin{array}{c}\text { Small-Pore } \\
\text { Unconsolidated }\end{array}$ & 40 & $252.1(85.4) \hat{\top}$ & 1.1 & 2300 & 4 & $27.2(3.7) \hat{\uparrow}$ & 17.1 & 32.8 \\
\hline $\begin{array}{c}\text { Large-Pore } \\
\text { Unconsolidated }\end{array}$ & 86 & $581.5(53)$ & 1.8 & 2500 & 1 & 53.7 (NA) $\uparrow$ & 53.7 & 53.7 \\
\hline Mixed Sandstone & 320 & $505.6(41.7) \uparrow$ & 1.7 & 6200 & 328 & $24.5(0.4) \uparrow$ & 4.3 & 52.9 \\
\hline $\begin{array}{l}\text { Fractured } \\
\text { Sandstone }\end{array}$ & 147 & $111.9(21)$ & 0.1 & 1800 & 21 & $13.2(1.1)$ & 5.3 & 21.4 \\
\hline Igneous Rock & 13 & $13.4(4.7)$ & 0.1 & 50 & 4 & $1.5(0.9)$ & 0.4 & 4.1 \\
\hline $\begin{array}{l}\text { Metamorphic } \\
\text { Rock }\end{array}$ & 71 & 16.1 (3.9) & 0.1 & 180 & 0 & NA & NA & NA \\
\hline $\begin{array}{c}\text { Mudstones \& } \\
\text { Siltstones }\end{array}$ & 176 & $51.7(9.2)$ & 0.2 & 1300 & 35 & $16.1(1.4)$ & 2.3 & 32.8 \\
\hline
\end{tabular}


Table 3: Number of samples, the mean concentration, and standard error of DO, DOC, $\mathrm{NO}_{3}$, and Ca for each of the geo-habitats. Arrows indicate significantly higher $\uparrow$ or lower $\downarrow$ levels of a parameter than the 'control' (in italic) geo-habitat (Igneous Rock) according to multiple pairwise comparisons (Bonferroni corrected).

\begin{tabular}{|c|c|c|c|c|c|c|c|c|}
\hline Geo-Habitat & $\begin{array}{c}\text { Number } \\
\text { of } \\
\text { Samples }\end{array}$ & $\begin{array}{c}\text { DO } \\
\text { (mg/L) } \\
\text { (se) }\end{array}$ & $\begin{array}{l}\text { Number } \\
\text { of } \\
\text { Samples }\end{array}$ & $\begin{array}{c}\text { DOC } \\
\text { (mg/L) } \\
\text { (se) }\end{array}$ & $\begin{array}{l}\text { Number } \\
\text { of } \\
\text { Samples }\end{array}$ & $\begin{array}{c}\mathrm{NO}_{3}-\mathrm{N} \\
(\mathrm{mg} / \mathrm{L}) \\
(\mathrm{se})\end{array}$ & $\begin{array}{l}\text { Number } \\
\text { of } \\
\text { Samples }\end{array}$ & $\begin{array}{c}\mathrm{Ca}(\mathrm{mg} / \mathrm{L}) \\
\text { (se) }\end{array}$ \\
\hline $\begin{array}{l}\text { Mildly Karstic } \\
\text { Chalk }\end{array}$ & 294 & $6.8(0.2)$ & 247 & $6.3(1.7) \boldsymbol{\uparrow}$ & 623 & $7.7(0.2)$ & 680 & $110.5(1.4)$ \\
\hline $\begin{array}{l}\text { Mildly Karstic } \\
\text { Limestone }\end{array}$ & 36 & $3.2(0.5) \downarrow$ & 36 & $2.1(0.3)$ & 105 & $3.6(0.4) \downarrow$ & 112 & $107.7(7.1)$ \\
\hline $\begin{array}{c}\text { Moderately } \\
\text { Karstic Limestone }\end{array}$ & 107 & $5.1(0.3) \downarrow$ & 89 & $6.3(2.4) \uparrow$ & 104 & $8.6(0.6)$ & 171 & $107.7(3.9)$ \\
\hline $\begin{array}{l}\text { Highly Karstic } \\
\text { Limestone }\end{array}$ & 100 & $6.3(0.3)$ & 98 & $1.7(0.2)$ & 181 & $3(0.3) \downarrow$ & 229 & $80.4(2.9)$ \\
\hline $\begin{array}{c}\text { Small-Pore } \\
\text { Unconsolidated }\end{array}$ & 57 & $3.2(0.4) \downarrow$ & 60 & $5.1(2.3)$ & 31 & $10.6(2.7)$ & 73 & 69 (3.9) \\
\hline $\begin{array}{c}\text { Large-Pore } \\
\text { Unconsolidated }\end{array}$ & 13 & $4.3(0.8) \downarrow$ & 21 & $2.1(0.3)$ & 67 & $11.6(1.3)$ & 85 & $120.1(7.3)$ \\
\hline Mixed Sandstone & 420 & $4.8(0.1) \downarrow$ & 310 & $4.1(0.4) \uparrow$ & 682 & $6(0.3)$ & 844 & $97.2(3.3)$ \\
\hline $\begin{array}{l}\text { Fractured } \\
\text { Sandstone }\end{array}$ & 115 & $5.7(0.3) \downarrow$ & 79 & $1.5(0.1)$ & 204 & $2.6(0.2) \downarrow$ & 282 & $44.62 .2)$ \\
\hline Igneous Rock & 79 & $7.5(0.3)$ & 39 & $1.4(0.2)$ & 209 & $6.3(0.3)$ & 213 & $14.9(0.7)$ \\
\hline $\begin{array}{l}\text { Metamorphic } \\
\text { Rock }\end{array}$ & 3 & $8.1(1.6)$ & 5 & $1.8(0.6)$ & 7 & $8.5(3.8)$ & 7 & $35.4(6)$ \\
\hline $\begin{array}{l}\text { Mudstones \& } \\
\text { Siltstones }\end{array}$ & 139 & $4.9(0.3) \downarrow$ & 14 & $5.8(3.1)$ & 129 & $2.5(0.3) \downarrow$ & 202 & $32.2(2.2)$ \\
\hline
\end{tabular}




\section{Figures}

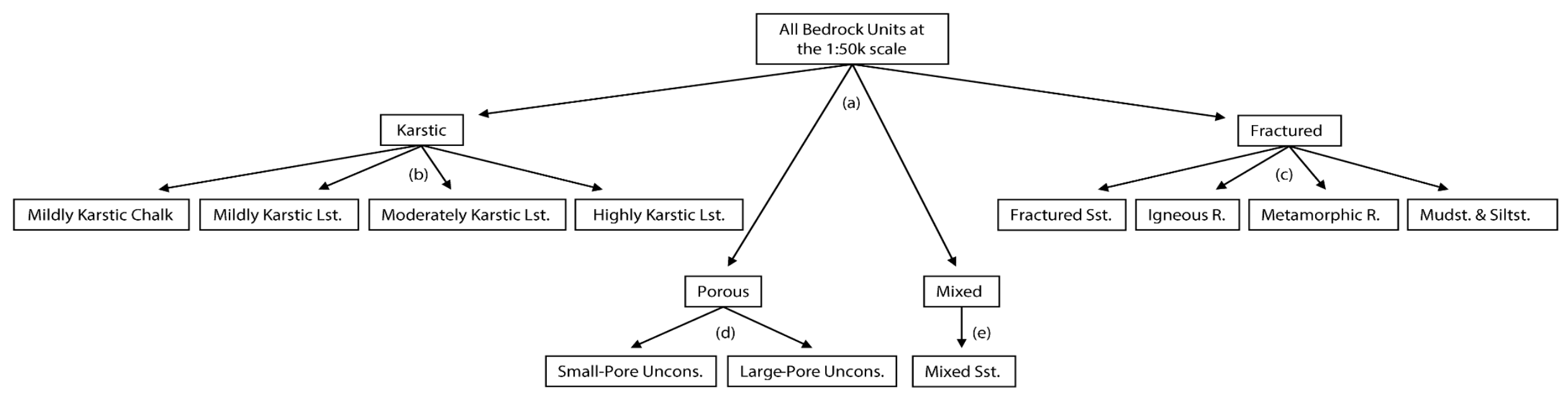

Figure 1: The geo-habitat categorisation process. Lst. $=$ Limestone, Sst. $=$ Sandstone, $R .=$ Rock, Mudst. \& Siltst. $=$ Mudstones \& Siltstones, Uncons. = Unconsolidated 


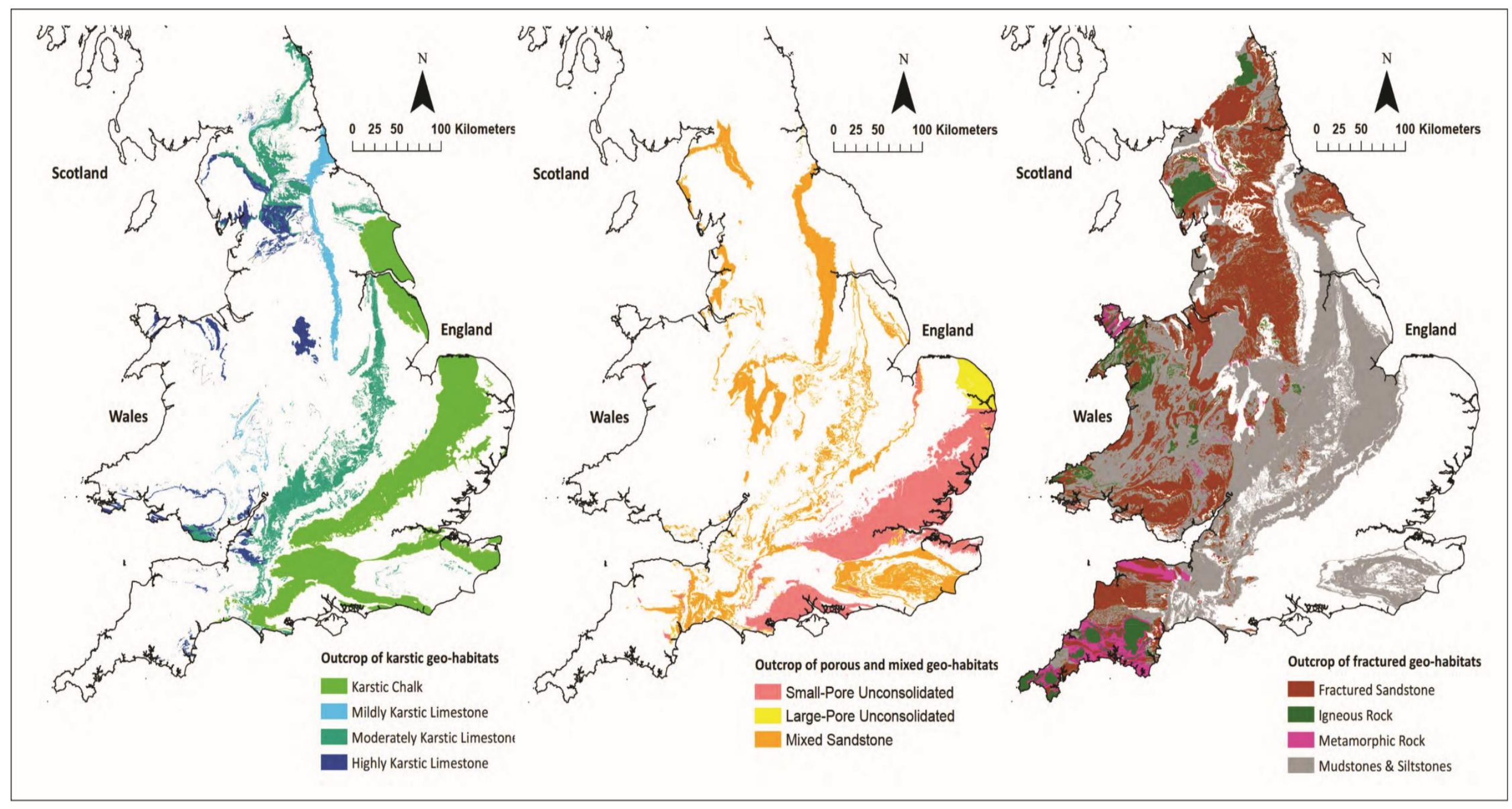

Figure 2: Distribution maps of the outcrop of groundwater geo-habitats in England and Wales. Contains British Geological Survey materials (C) NERC 2017. Contains Ordnance Survey data @ Crown Copyright and database rights 2017. 


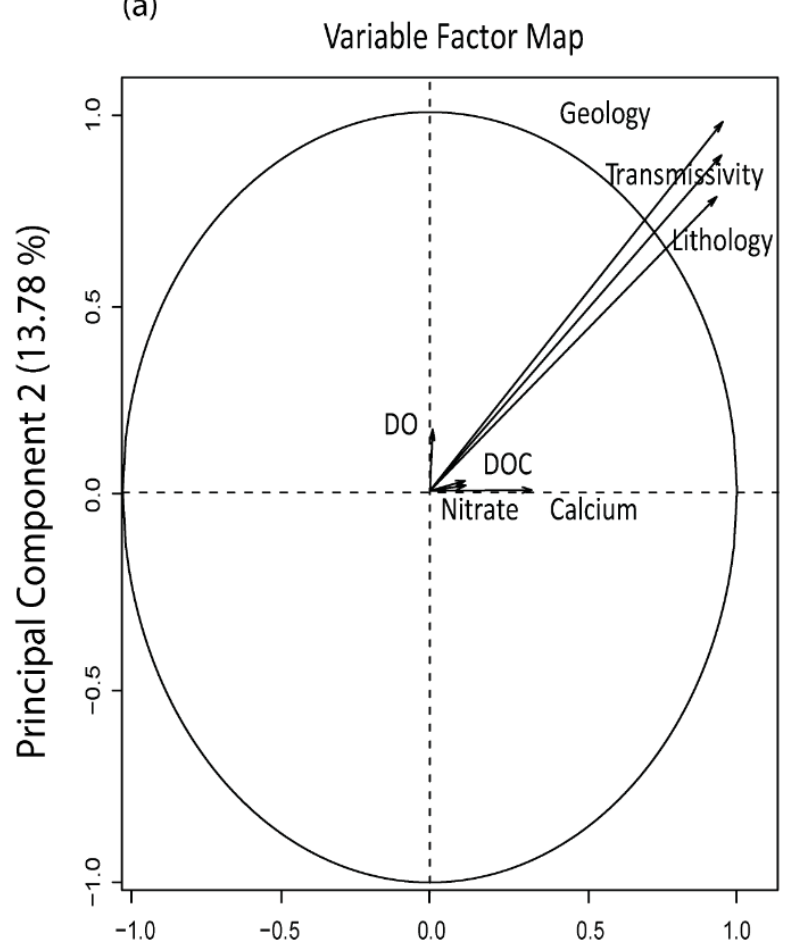

(b)

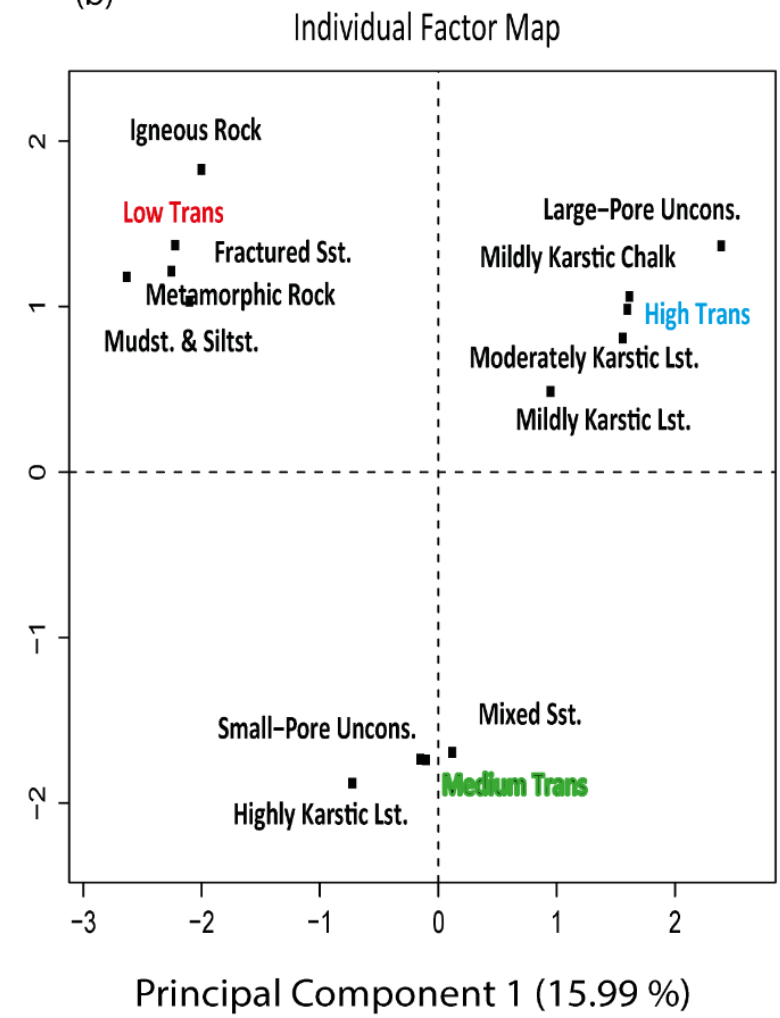

(c)

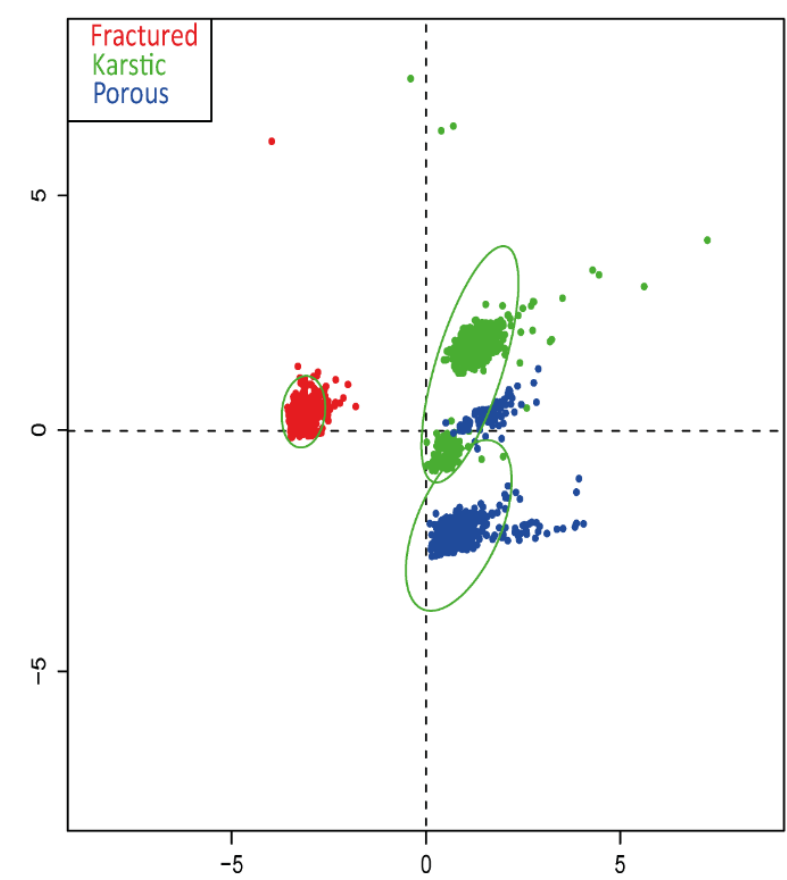

Figure 3: (a) Ordination of environmental variables in a Principal Component Analysis (PCA), explaining a total of $29.77 \%$ of data variance. (b) Ordination of geo-habitats grouped by different colour-coded transmissivities (low, medium, high). (c) Ordination of broad lithologies (fractured, karstic, porous habitats) with individual colour-coding. Confidence ellipsoids around different groups indicate differences between broad lithologies. 


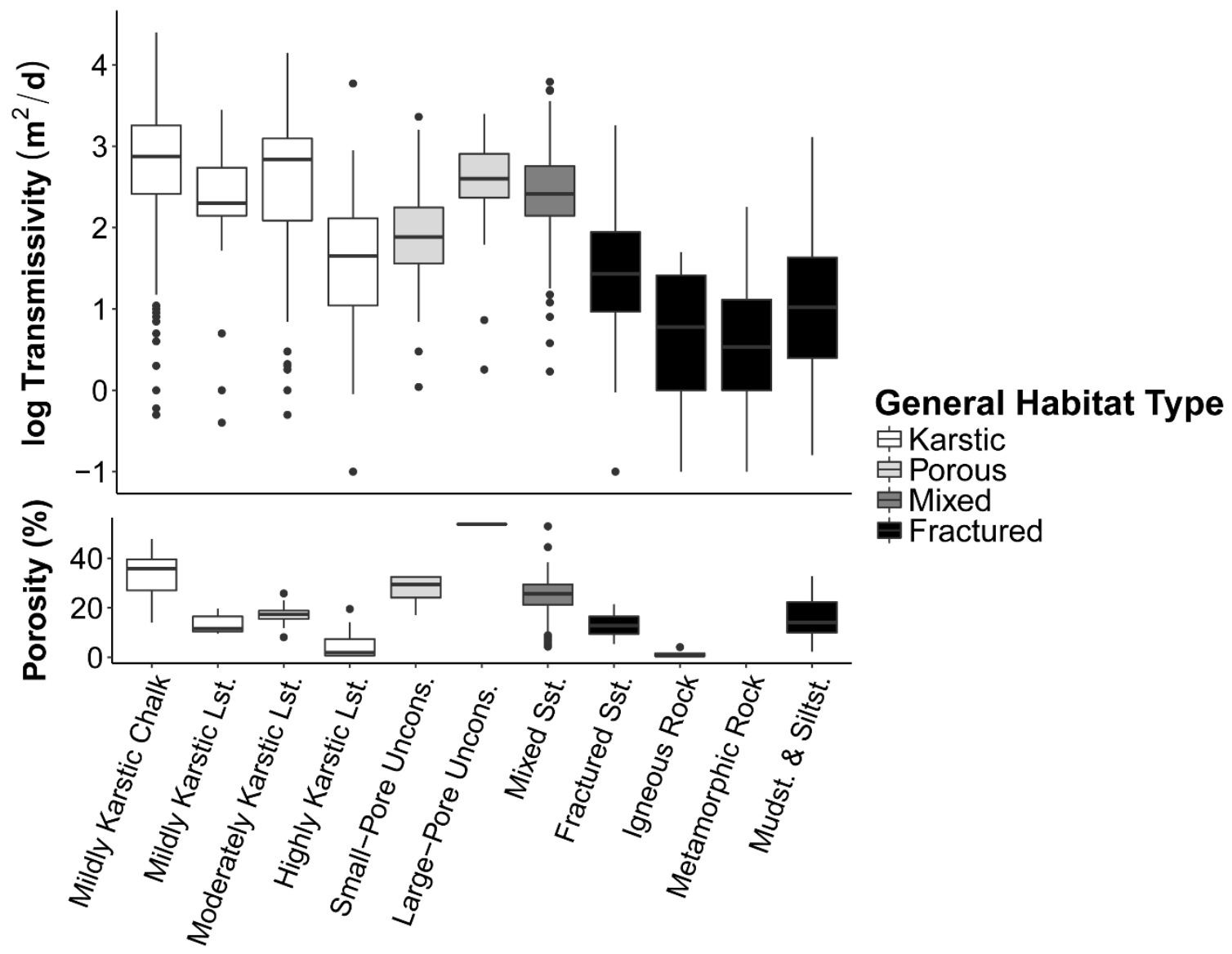

\section{Geo-Habitat}

Figure 4: Hydrogeological variables for the 11 geo-habitats showing (a) log Transmissivity $\left(\mathrm{m}^{2} / \mathrm{d}\right)$ and (b) Porosity (\%), with the horizontal band representing the medium, the bottom and top of the box representing the first and third quartiles, and the whiskers representing one standard deviation above and below the mean. No porosity data was available for Metamorphic Rock. Lst. = Limestone, Sst. = Sandstone, Mudst. \& Siltst. = Mudstones \& Siltstones 


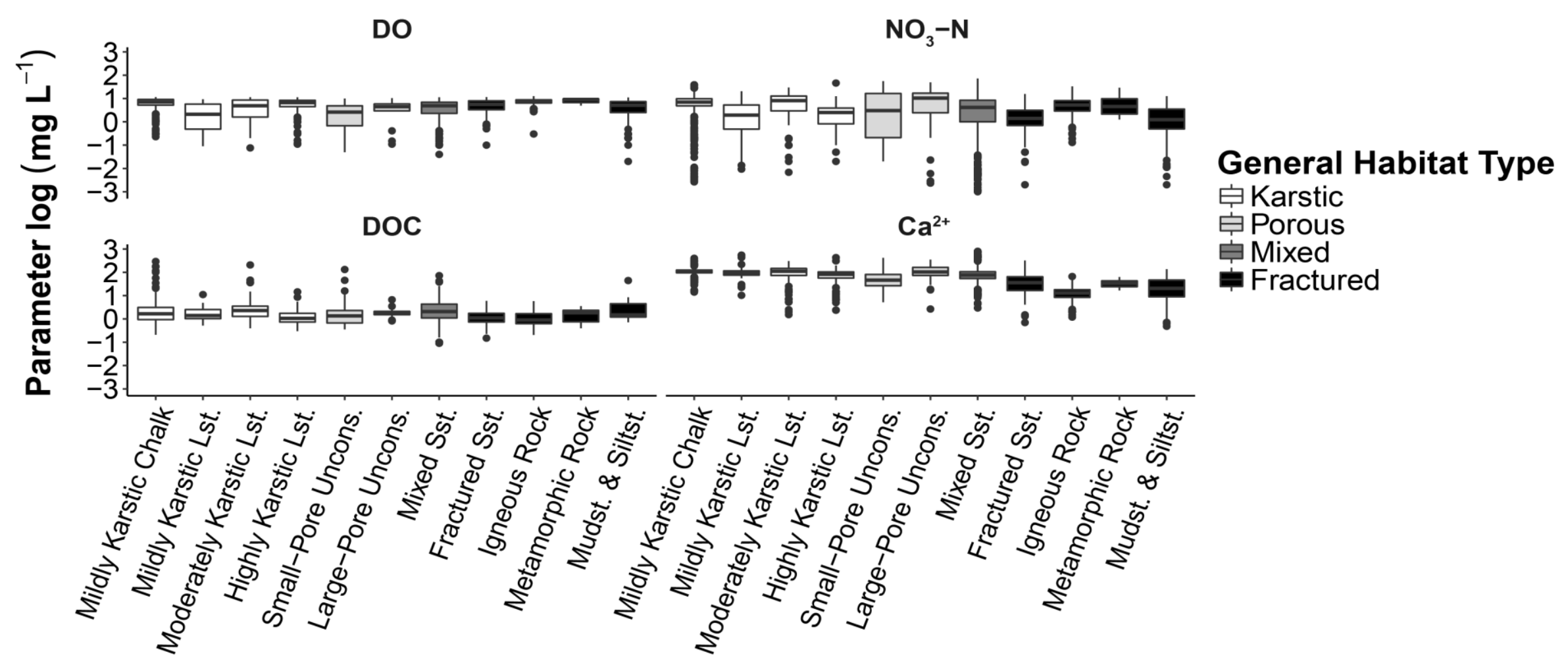

\section{Geo-Habitat}

Figure 5: Hydrochemical variables for the 11 geo-habitats showing logs of $D O, D O C, C a$ and $\mathrm{NO}_{3}$ (all in $\mathrm{mg} / \mathrm{L}$ ), with the horizontal band representing the medium, the bottom and top of the box representing the first and third quartiles, and the whiskers representing one standard deviation above and below the mean. Lst. = Limestone, Uncons. = Unconsolidated, Sst. = Sandstone, Mudst. \& Siltst. = Mudstone \& Siltstone 


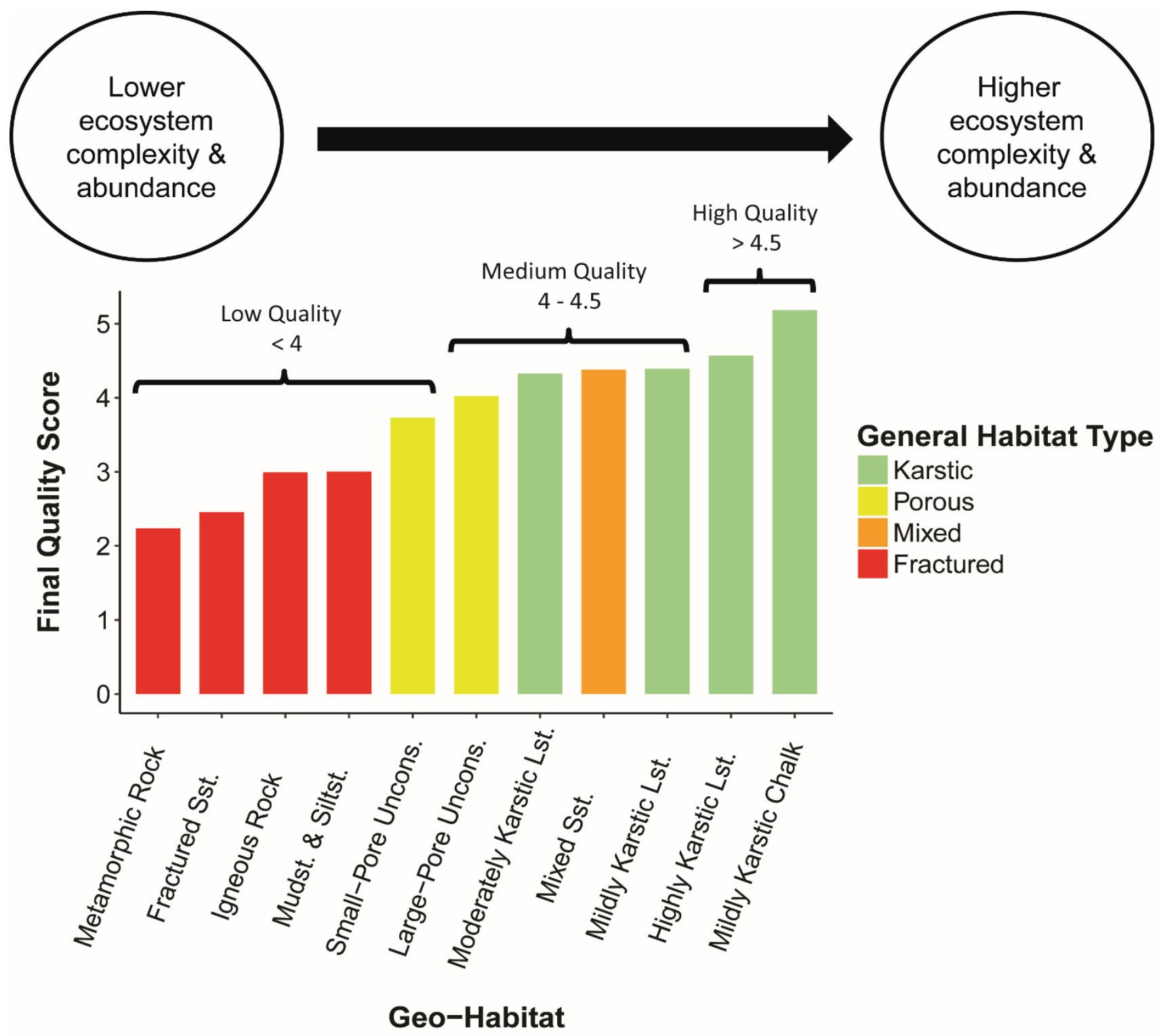

Figure 6: Log geo-habitat quality scores sorted from lowest to highest. 


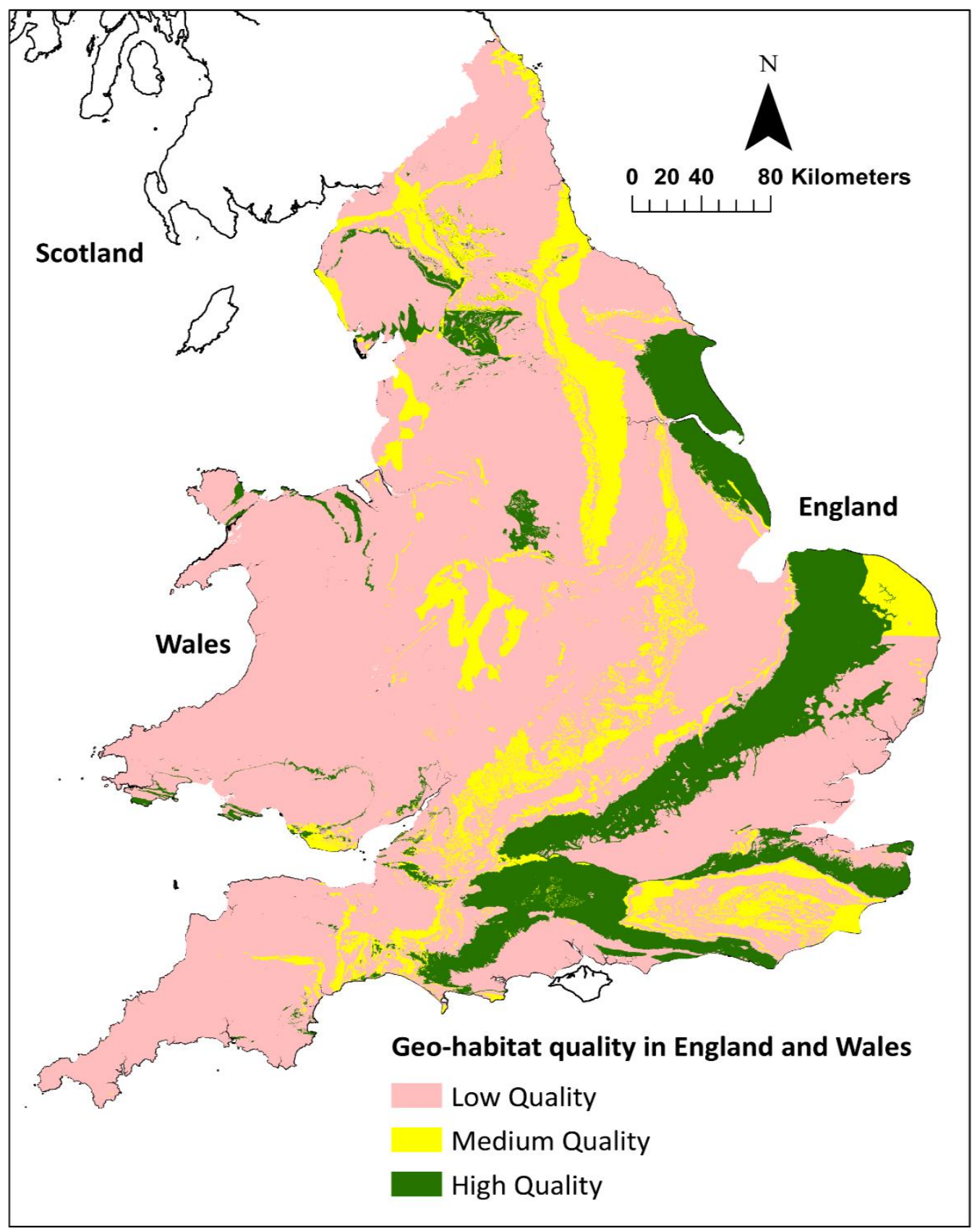

Figure 7: Distribution map of groundwater habitats in England and Wales grouped by their habitat quality scores calculated from abiotic parameters important to groundwater ecosystems. Contains British Geological Survey materials (C) NERC 2017. Contains Ordnance Survey data (C) Crown Copyright and database rights 2017. 